IN brief

\section{Bye-bye WilBio}

As the biotech sector reels from the global financial crisis, so too are firms providing services to the industry. Williamsburg Bioprocessing Foundation (Wilbio), a private company based in Virginia Beach, Maryland, that organized meetings for firms manufacturing biological products, closed its doors June 30 after 15 years of operation. During its lifetime, Wilbio organized 13 annual conferences, consisting of traditional speaker presentations together with workshops where exhibitors showcased products. According to Keith Carson, Wilbio's founder, former chairman and CEO, the Monoclonal and Recombinant Antibodies conference was the largest, attracting 400 attendees at its peak, and other longstanding conferences included Viral Vectors and Vaccines, Cell \& Tissue BioProcessing and The Baculovirus and Insect Cell Culture Conference. Laurent Humeau, vice president of research and development for Gaithersburg, Maryland-based Virxsys, a firm focusing on gene therapy using lentiviral vector delivery, says his company had been attending Wilbio conferences annually since 2002. Humeau believes that the small size of the meetings were both an advantage and a weakness for Wilbio. Carson cites several factors for the company's loss of profitability: a spate of mergers and acquisitions that ate up small companies, many of which participated as sponsors and exhibitors, layoffs and cost-cutting triggered by the financial crisis, as well as the swine flu pandemic, which may have made people reluctant to fly. Nazlie Latefi

\section{GM fish ice cream}

Italian media have cried foul over Unilever's plans to sell ice creams containing fish antifreeze proteins this summer. The European Commission granted marketing authorization in April, but ice creams containing ice structuring protein (ISP) derived from fish will not be available in Europe until next year. Approval came "too late for this summer, in time for 2010," says Anne Heughan, external affairs director for Unilever, of London and Rotterdam, Netherlands. Several hundred million ice creams containing ISP have already been sold in the US, Australia, New Zealand, the Philippines and Brazil. The antifreeze ISP, produced in yeast engineered with a gene from the fish Macrozoarces americanus, provides stability and texture to low-fat products by inhibiting ice-crystal growth. In Europe, labels won't include the words genetically modified (GM) because processing aids fall outside the GM food regulation (1829/2003). Antifreeze proteins are widely distributed in nature but Heughan says Unilever selected fish ISP "for all the benefits, from creaminess to nutritional content." Applications for antifreeze proteins could be numerous as recrystallization reduces the palatability of all frozen foods. Ice cream came first because mixing is easy, whereas delivering antifreeze proteins into tissues, for example in shrimp, is more difficult, explains Dan Yang of Dundas, Ontario, Canada's Ice Biotech. Anna Meldolesi

\section{Novo awaits green light for diabetes drug}

As Nature Biotechnology went to press, Novo Nordisk awaited a decision from the US Food and Drug Administration (FDA) on its weekly, anti-diabetic drug Victoza (liraglutide). After the European Commission's approval of Victoza in July, the Bagsvaerd, Denmark-based giant biotech is upbeat about its drug's prospects. Standing in the path of Victoza's FDA approval, however, are preclinical findings, originally discussed during an FDA Endocrinologic and Metabolic Drugs Advisory Committee in April, that suggest C-cell thyroid cancer could be a potential safety concern associated with the drug. And even though clinicians are optimistic about the company's ability to address these tumorigenicity concerns, Victoza faces several hurdles before commercial success: a diabetes market already crowded with smallmolecule drugs, a long-acting form of Byetta (exenatide; synthetic exendin-4) that could be launched as soon as next year and uncertainty as to whether the FDA will follow the positive opinion of its European regulatory counterpart.

The Danish company is banking on Victoza's approval to secure a significant tranche of the multibillion-dollar type 2 diabetes market currently tapped by Byetta, Amylin Pharmaceuticals/Eli Lilly's first-inclass synthetic molecule originally isolated from the salivary venom of Gila lizard, which mimics the activity of human glucoselowering peptide-1 (GLP-1) and was originally approved in 2005. "The type 2 diabetes market occupied around $\$ 15$ billion in 2008," says Sylvia Miriyam Findlay, program leader for Frost \& Sullivan's pharmaceuticals and biotech in London. "By 2013, it is likely to reach $\$ 22$ billion.” Novo believes that Victoza has an edge over Byetta owing to its improved pharmacokinetic/pharmacodynamic profile: Victoza is injected weekly, whereas Byetta must be administered twice daily.

Recombinant versions of GLP-1 represent an important new alternative to insulin treatment because they tap into a new, potent pathway for lowering blood glucose levels. After food intake, naturally occurring GLP-1, an incretin hormone, is released by gut L-cells, activating several mechanisms that, acting in concert, help lower blood glucose levels (Fig. 1). GLP-1 analogs mimic the glucose-lowering actions of incretin. They delay gastric emptying, which helps limit post-prandial glucose, dampen inappropriate glucagon release (glucagon has the opposite effect to insulin), enhance insulin sensitivity in peripheral tissues and reduce appetite, probably through an effect on the hypothalamus.

Although some antihyperglycemic drugs, such as sulfonylureas, directly increase insulin release, GLP-1 receptor agonists stimulate only insulin secretion in the presence of elevated glucose concentrations. This could explain why Victoza does not cause major hypoglycemic events, one of the major adverse events associated with other therapies.

Treatment for type-2 diabetes starts with lifestyle changes-improved diet and increased exercise. If that fails, physicians prescribe sulfonylureas that prompt pancreatic beta cells to release more insulin. Biguanides, such as metformin, and thiazolodinediones (e.g., Avandia; rosiglitazone maleate) reduce glucose production by the liver and increase insulin sensitivity. Those patients with advanced disease must also resort to injecting insulin directly.

\section{SELECTED research collaborations}

\begin{tabular}{lll} 
Partner 1 & Partner 2 & \$ (millions) \\
\hline Catalyst (S. San Francisco, California) & $\begin{array}{l}\text { Medlmmune (Gaithersburg, Maryland)/ } \\
\text { AstraZeneca (London) }\end{array}$ & 195
\end{tabular}

Geron (Menlo Park, California) GE Healthcare (Buckinghamshire, UK)

Archemix (Cambridge, Massachusetts) Dicerna (Watertown, Massachusetts)

Bayer (Leverkusen, Germany)

Monsanto (St. Louis)

*Financial details not disclosed 